\title{
The elusive link between high sensitivity C-reactive protein and carotid subclinical atherosclerosis in coronary artery bypass grafting candidates: A cross-sectional study
} Parvin Shakouri ${ }^{1}$, Nariman Nezami ${ }^{2,3}$, Mohammad Kazem Tarzamni*1,3 and Reza Javad Rashid ${ }^{1}$

Address: ${ }^{1}$ Department of Radiology, Tabriz University of Medical Sciences, Tabriz, Iran, ${ }^{2}$ Young Researchers Club, Tabriz Islamic Azad University, Tabriz, Iran and ${ }^{3}$ Drug Applied Research Center, Tabriz University of Medical Sciences, Tabriz, Iran

Email: Parvin Shakouri - Shakouriparvin@hotmail.com; Nariman Nezami - Dr.Nezami@gmail.com; Mohammad Kazem Tarzamni* - Tarzamni@yahoo.com; Reza Javad Rashid - RJRashid@hotmail.com

* Corresponding author

Published: 30 May 2008

Cardiovascular Ultrasound 2008, 6:23 doi:10.1186/1476-7/20-6-23
Received: II April 2008

Accepted: 30 May 2008

This article is available from: http://www.cardiovascularultrasound.com/content/6/I/23

(c) 2008 Shakouri et al; licensee BioMed Central Ltd.

This is an Open Access article distributed under the terms of the Creative Commons Attribution License (http://creativecommons.org/licenses/by/2.0), which permits unrestricted use, distribution, and reproduction in any medium, provided the original work is properly cited.

\begin{abstract}
Background: Previous studies demonstrated a modest association between C-Reactive Protein (CRP), stenosis of carotid artery, and carotid Intima-Media Thickness (IMT) in general population. During present study, we aimed to evaluate the relationship between High Sensitivity C-Reactive Protein (hsCRP) and Common Carotid Intima-Media Thickness (CCIMT) in patients who candidate for Coronary Artery Bypass Grafting (CABG).
\end{abstract}

Methods: The study subjects were enrolled from patients with coronary arteries disease referred from Shahid Madani Hospital (Tabriz, Iran), who have been candidate for elective CABG from January 2005 to August 2007. The common carotid arteries were evaluated with high-resolution B-mode ultrasonography using a 7.5- $\mathrm{MHz}$ linear-array transducer to determine the IMT and grade of stenosis. Serum hsCRP level was measured using commercially available enzyme linked immunosorbent assay kit.

Results: Finally, information of 176 CABG candidates was analysed. The mean age of participants was $62.71 \pm 9.45$ years with 1.63 male to female ratio. The mean of CCIMT was $0.69 \pm 0.54 \mathrm{~mm}$. Although there was no significant correlation between serum hsCRP level and CCIMT in patients without carotid stenosis $(p=0.113, r=0.186)$, participants with common carotid artery stenosis had higher levels of serum hsCRP than participants without stenosis $(2.42+/-1.30$ vs. $1.20+/-0.97 \mathrm{mg} / \mathrm{dl}$; $\mathrm{p}=0.009$ ).

Conclusion: Study results showed that there was no correlation between serum hsCRP level and CCIMT in patients without carotid stenosis, but patients with common carotid artery stenosis had higher levels of serum hsCRP than patients without stenosis. 


\section{Background}

Assessment of carotid arteries stenosis and Intima-Media Thickness (IMT) by high resolution B-mode ultrasonography have been shown correlated with prevalence of cardiovascular disease, myocardial infarction, and stroke [1-3]. Some previous studies reported higher risk of myocardial infarction and stroke for patients who had higher levels of carotid arteries IMT $[3,4]$. In addition to these reports, results of other investigators demonstrated a modest association between C-Reactive Protein (CRP) and carotid artery stenosis and IMT $[1,5,6]$. As we know from previous studies, atherosclerosis considered to reflect chronic inflammation in arterial walls [7,8]. Patients cancidate for Coronary Artery Bypass Grafting (CABG) have higher level of atherosclerosis, so we aimed to determine the Common Carotid Intima-Media Thickness (CCIMT), High Sensitivity C-Reactive Protein (hsCRP) level, and their relationship in CABG candidates.

\section{Methods}

\section{Study population}

The study subjects were enrolled from consecutive patients of the Shahid Madani Hospital (Tabriz, Iran), who have been candidate for elective CABG from January 2005 to August 2007. In our referral center, all of CABG candidates underwent carotid and femoral arteries Doppler study, preoperatively.

Patients who had carotid endartrectomy, collagen-vascular diseases, diabetes, infection diseases history during recent month, inflammatory gastroenterology diseases, multiple sclerosis, liver diseases, end stage renal disease and previous stroke were excluded. The base-line examination included a medical history and laboratory testing.

\section{Ethical consideration}

The study was performed according to the guidelines of Helsinki declarartion and approved by the Tabriz University of Medical Sciences Ethics Committee. All participants gave informed consent before including to the study.

\section{Carotid ultrasonographic evaluation}

The common carotid arteries were evaluated with highresolution B-mode ultrasonography using a 7.5- $\mathrm{MHz}$ linear-array transducer (Hitachi model EUB-525; Hitachi Medical Corp., Tokyo, Japan) to determine the IMT, site of plaques, and stenosis grade. Participants were examined in a supine position, with the head in the axis of the body slightly tilted to the either side. The IMT was measured in common carotid artery at sites 1.0 and $3.0 \mathrm{~cm}$ proximal from the beginning of carotid bulb and at the bottom of the bulb. The IMT was defined as the distance between two parallel echogenic lines corresponding to the bloodintima and media-adventitia interfaces. The average value of the 3 points was calculated for each side and the largest value (maximum IMT) was used for analysis.

The common carotid arteries were scanned cross-sectionally and longitudinally. All ultrasound measurements were recorded in end diastole and were measured by the investigator blinded to patients' clinical state. Plaque was defined as a regional intimal thickening, more than 1.2 $\mathrm{mm}$ in IMT height. In patients with plaque, carotid artery stenosis was graded using the peak systolic velocity measured after the plaque site according to the Society of Radiologists in Ultrasound Consensus Criteria [9].

\section{Serum hsCRP assay}

At baseline examination, a blood sample from every participant was drawn and centrifuged at $1500 \mathrm{rpm}$ for 5 minutes, and then the serum samples were stored at $70^{\circ} \mathrm{C}$. All of samples were thawed together, and hsCRP was determined using commercially available enzyme linked immunosorbent assay kit (Monobind, Inc., Lake Forest, CA, USA; Lot Num: EIA-31K2A1).

\section{Statistical methods}

Data analysis was performed using the SPSS package version 13 (Chicago, IL, USA). Continuous variables were compared between groups using parametric independent sample $t$-test, and oneway-ANOVA, or nonparametric Man-Whitney U test, and Kruskal walls. $\mathrm{X}^{2}$ test also was used to analysis significant difference of categorized data. Pearson correlation and multiple regression were applied to evaluate the relationship of hsCRP level with CCIMT in patients without stenosis. A value of $p<0.05$ was considered significant.

\section{Results}

Finally, information of 176 CABG candidates was analysed. Demographic charcterstics of participants were listed in Table 1. Frequency of various grades of common carotid stenosis was shown in Table 2 based on right and left sides. Figure 1 demonstrated frequency of common carotid artery stenosis in study population. The mean of CCIMT was $0.69 \pm 0.54 \mathrm{~mm}$.

Although there was no significant correlation between serum hsCRP level and CCIMT ( $\mathrm{p}=0.113, \mathrm{r}=0.186)$, participants with stenosis had higher levels of serum hsCRP than participants without stenosis in common carotid $\operatorname{artery}(2.42 \pm 1.30$ vs. $1.20 \pm 0.97 \mathrm{mg} / \mathrm{dl} ; \mathrm{p}=0.009)$.

In comparison of serum hsCRP levels among the various stenosis grades of common carotid artery, there were no significant difference between patients with $<50 \%$ stenosis, $50-60 \%$ stenosis, and 70-to near occlusion ( $p>0.05$; Table 3). 


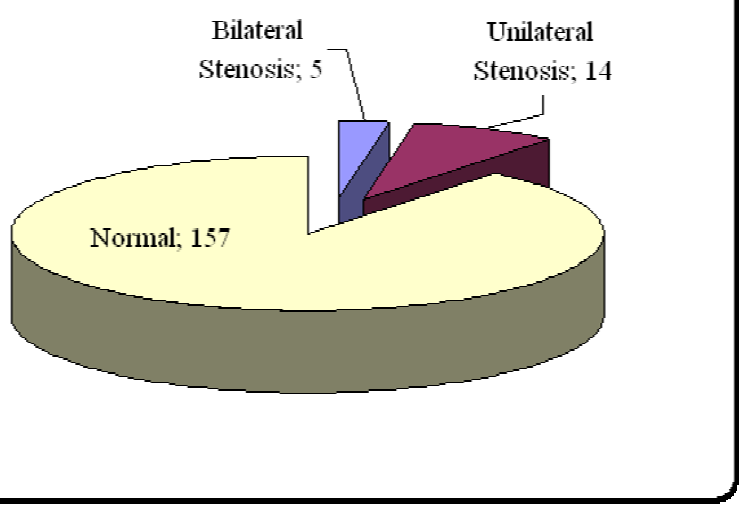

Figure I

Frequency of common carotid artery stenosis in study population.

There was a direct linear correlation between age and CCIMT ( $p=0.016, \mathrm{r}=0.239)$ in participants whitout stenosis.

\section{Discussion}

This study examined the association of hsCRP with CCIMT. Study results showed that there was no correlation between hsCRP and CCIMT in CABG candidates with subclinical atherosclerosis. Despite this fact, patients with common carotid artery stenosis had higher levels of hsCRP than patients without stenosis. During present study, we strove to control conventional cardiovascular risk factors and diseases which may be affected hsCRP level. Furthermore, this study showed a lower incidence of severe carotid stenosis in Iranian population who candidate for CABG; like previous report of Tarzamni et al. for Iranian [10], and in contrast to the previous studies for other populations [11-14].

Several epidemiological studies have shown a link between serum hsCRP level and subsequent cardiovascular disease in general population [15-19]. In respect to the carotid atherosclerosis, an association between CRP levels and the presence of carotid plagues has been demonstrated by univariate analysis in a prospective studies conducted in general community, or in healthy middle aged women with a smoking history [20-22]. However, this relationship between IMT and CRP level appeared to be largely dependant on age or the presence of other cardiovascular risk factors. In contrast to the previous studies finding, other studies which carried out under controlled criteria failed to show a relation between CRP and carotid IMT and plaque formation $[23,24]$.
Table I: Demographic characteristics of participants.

\begin{tabular}{llc}
\hline Variable & & Value \\
\hline Age (years) & & $62.71 \pm 9.45$ \\
BMI $\left(\mathrm{Kg} / \mathrm{m}^{2}\right)$ & & $28.31 \pm 3.74$ \\
Gender & Male & $109(61.93 \%)$ \\
& Female & $67(38.07 \%)$ \\
Male/female ratio & & 1.63 \\
Smoking history & Male & $58(54.12 \%)$ \\
& Female & $6(8.95 \%)$ \\
Smoking (Current/Former) & Male & $13(11.92 \%) / 45(42.19 \%)$ \\
& Female & $0(0.0 \%) / 6(8.95 \%)$ \\
Systolic blood pressure $(\mathrm{mm} \mathrm{Hg})$ & & $148.32 \pm 24.43$ \\
Diastolic blood pressure $(\mathrm{mm} \mathrm{Hg})$ & & $91.54 \pm 18.26$ \\
Anti-hypertensive therapy & & $70.45 \%$ \\
Lipid-lowering agent intake & & $46.02 \%$ \\
& & \\
\hline
\end{tabular}

To the best of our knowledge, this study is the first one that evaluated relationship of hsCRP and CCIMT among the CABG candidates. Study findings, in contrary with some previous reports $[6,25]$, demonstrated that elevated level of hsCRP was not associated with increased IMT. While patients with carotid artery stenosis had higher level of serum hsCRP, there was not statistcally significant difference between various grades of stenosis. As we know, patients who candidate for CABG have higher grades of atherosclerosis in coronary arteries. Today, atherosclerosis consider as a chronic inflammatory process $[7,8]$, and innate and adaptive immune responses participate in several phases of atherosclerosis [26]. CRP is a component of innate immunity that is actively participates in inflammatory process. Recent evidences have suggested a possible direct pathogenic role for CRP in atherosclerosis process and plaque formation [27-29] and increasing of CRP level promote arterial atherosclerosis. Alternatively, it may merely be an epiphenomena and an indicator of systemic inflammation which itself is associated with atherosclerosis.

Furthermore, some of conventional cardiovascular risk factors such as smoking, obesity may act to increase atherosclerosis partly through increasing systemic inflammation. The systemic inflammatory response is also increased in smokers according to the pack pear year of smoking [23]. This may be related to both of bacterial endotoxin and the increased risk of respiratory tract infection seen in smokers [30]. Therefore, elevated CRP may merely reflect an exaggerated inflammatory response associated with these conventional cardiovascular risk factors [31,32].

As well-known ligand of phosphorylcholine residues, CRP binds avidly to oxidized low-density lipoproteins and may induce foam cell formation in atherosclerosis $[33,34]$. In this case and by considering the patients with 
Table 2: Categorization of patients according to the stenosis grade of Common Carotid Artery (CCA).

\begin{tabular}{lcccc}
\hline & & & Grade of stenosis \\
\cline { 2 - 4 } & Normal & $<50 \%$ & $50-69 \%$ & $70 \%$-near to occlusion \\
\hline $\begin{array}{l}\text { Right CCA } \\
\text { Left CCA }\end{array}$ & 166 & 7 & 2 & 1 \\
\hline
\end{tabular}

Table 3: hsCRP by stenosis grades.

\begin{tabular}{|c|c|c|c|c|}
\hline & \multicolumn{4}{|c|}{ Stenosis grades of common carotid artery } \\
\hline & Normal & $<50 \%$ & $50-69 \%$ & $70 \%$ to near occlusion \\
\hline Serum hsCRP (mg/dl) & $1.21 \pm 0.97$ & $2.18 \pm 1.22$ & $2.49 \pm 1.25$ & $2.27 \pm 1.42$ \\
\hline
\end{tabular}

carotid artery stenosis had higher serum hsCRP levels, the CRP effect might be confirmed clinically by study results.

Despite these findings, one of our study limitations was limited population. So, we struggled to use proper statistical tests to analysis data and appropriate inclusion and exclusion criteria to control any factors may address any bias.

\section{Conclusion}

In conclusion, our study results showed that there was no correlation between serum hsCRP level and intima-media thickness of common carotid in patients without stenosis, but patients with common carotid artery stenosis had higher levels of serum hsCRP than patients without stenosis.

\section{Abbreviations}

IMT: Intima-Media Thickness; CRP: C-Reactive Protein, hsCRP: High-Sensitivity C-Reactive Protein; CABG: Coronary Artery Bypass Grafting; CCIMT: Common Carotid Intima-Media Thickness

\section{Competing interests}

The authors declare that they have no competing interests.

\section{Authors' contributions}

PS designed study and performed Doppler ultrasonographic evaluation.

NN followed up the patients, performed data analysis, drafted and revised the manuscript

MKT conceived the paper, and carried out the Doppler ultrasound
RJR participated in coordination and enrolment of patients to the study

All authors read and approved the final manuscript.

\section{Acknowledgements}

We are most grateful to the patients participating in this study. Written informed consent was also obtained for publication from the patients and/ or their relatives.

\section{References}

I. Burke GL, Evans GW, Riley WA, Sharrett AR, Howard G, Barnes RW, Rosamond W, Crow RS, Rautaharju PM, Heiss G: Arterial wall thickness is associated with prevalent cardiovascular disease in middle-aged adults. The Atherosclerosis Risk in Communities (ARIC) study. Stroke 1995:386-39I.

2. O'Leary DH, Polak JF, Kronmal RA, Manolio TA, Burke GL, Wolfson SK Jr: Carotid-artery intima and media thickness as a risk factor for myocardial infarction and stroke in older adults. Cardiovascular Health Study Collaborative Research Group. N Engl J Med 1999: I 4-22.

3. Bots ML, Hoes AW, Koudstaal PJ, Hofman A, Grobbee DE: Common carotid intima-media thickness and risk of stroke and myocardial infarction: the Rotterdam Study. Circulation 1997:1432-1437.

4. Schillinger M, Exner M, Mlekusch W, Sabeti S, Amighi J, Nikowitsch R, Timmel E, Kickinger B, Minar C, Pones M: Inflammation and Carotid Artery-Risk for Atherosclerosis Study (ICARAS). Circulation 2005:2203-2209.

5. Jarvisalo MJ, Harmoinen A, Hakanen M, Paakkunainen U, Viikari J, Hartiala J, Lehtimaki T, Simell O, Raitakari OT: Elevated serum Creactive protein levels and early arterial changes in healthy children. Arterioscler Thromb Vasc Biol 2002:1323-1328.

6. Wang TJ, Nam BH, Wilson PW, Wolf PA, Levy D, Polak JF, D'Agostino RB, O'Donnell Cl: Association of C-reactive protein with carotid atherosclerosis in men and women: the Framingham Heart Study. Arterioscler Thromb Vasc Biol 2002:1662-1667.

7. Ross R: Atherosclerosis-an inflammatory disease. N EnglJ Med 1999:115-126.

8. Libby P: Molecular bases of the acute coronary syndromes. Circulation 1995:2844-2850.

9. Grant EG, Benson CB, Moneta GL, Alexandrov AV, Baker JD, Bluth El: Carotid artery stenosis: gray-scale and Doppler US diagnosis - Society of Radiologists in Ultrasound Consensus Conference. Radiology 2003:340-346.

10. Tarzamni MK, Afrasyabi A, Farhoodi M, Karimi F, Farhang S: Low prevalence of significant carotid artery disease in Iranian 
patients undergoing elective coronary artery bypass. Cardiovasc Ultrasound 2007:I-5

II. Berens ES, Kouchoukos NT, Murphy SF, Waering TH: Preoperative carotid screening in elderly patients undergoing cardiac surgery. J Vasc Surg 1992:313-321.

12. Rath PC, Agarwala MK, Dhar PK, Lakshmi C, Ahsan SA, Deb T, Kumar S, NarasimhamR RS, Rao PS, Dixit V: Carotid artery involvement in patients of atherosclerotic coronary artery disease undergoing coronary artery bypass. Indian Heart J 200I:76I-765.

13. Salasidis GC, Latter DA, Steinmetz OK, Blair JF, Graham AM: Carotid artery duplex scanning in preoperative assessment for coronary artery revascularization : the association between peripheral vascular disease, carotid artery stenosis and stroke. J Vasc Surg 1995: I54-160.

14. Gasera B, Angelis I, Weingartnet J, Neurmaier PP, Spiliopoulos K, Kemkes BM: Simultaneous carotid endarterectomy and cardiac surgery - additional risk factor or safety? Thrac Cardiovasc Surg 2003:22-27.

15. Thompson SG, Kienast J, Pyke SD, Haverkate F, Loo JC van de: Hemostatic factors and the risk of myocardial infarction or sudden death in patients with angina pectoris. European Concerted Action on Thrombosis and Disabilities Angina Pectoris Study Group. N EnglJ Med 1995:635-64I.

16. Kuller LH, Tracy RP, Shaten J, Meilahn EN: Relation of C-reactive protein and coronary heart disease in the MRFIT nested case-control study. Multiple Risk Factor Intervention Trial. Am J Epidemiol 1996:537-547.

17. Tracy RP, Lemaitre RN, Psaty BM, Ives DG, Evans RW, Cushman M, Meilahn EN, Kuller LH: Relationship of C-reactive protein to risk of cardiovascular disease in the elderly. Results from the Cardiovascular Health Study and the Rural Health Promotion Project. Arterioscler Thromb Vasc Biol 1997: I | 21 I I I 27.

18. Haverkate F, Thompson SG, Pyke SD, Gallimore JR, Pepys MB: Production of $C$-reactive protein and risk of coronary events in stable and unstable angina. European Concerted Action on Thrombosis and Disabilities Angina Pectoris Study Group. Lancet 1997:462-466.

19. Ridker PM, Cushman M, Stampfer MJ, Tracy RP, Hennekens CH: Inflammation, aspirin, and the risk of cardiovascular disease in apparently healthy men. N Engl J Med 1997:973-979.

20. Makita S, Nakamura M, Hiramori K: The association of C-reactive protein levels with carotid intima-media complex thickness and plaque formation in the general population. Stroke 2005.2138-2142

21. Willeit J, Kiechl S, Oberhollenzer F, Rungger G, Egger G, Bonora E, Mitterer M, Muggeo M: Distinct risk profiles of early and advanced atherosclerosis: prospective results from the Bruneck Study. Arterioscler Thromb Vasc Biol 2000:529-537.

22. Hak AE, Stehouwer CD, Bots ML, Polderman KH, Schalkwijk CG, Westendorp IC, Hofman A, Witteman JC: Association of C-reactive protein with measures of obesity, insulin resistance, and subclinical atherosclerosis in healthy, middle-aged women. Arterioscler Thromb Vasc Biol 1999:1986-1991.

23. Tracy RP, Psaty BM, Macy E, Bovill EG, Cushman M, Cornell ES, Kuller $\mathrm{LH}$ : Lifetime smoking exposure affects the association of $C$. reactive protein with cardiovascular disease risk factors and subclinical disease in healthy elderly subjects. Arterioscler Thromb Vasc Biol 1997:2167-2176.

24. Lorenz MW, Karbstein P, Markus HS, Sitzer M: High-sensitivity Creactive protein is not associated with carotid intima-media progression: the carotid atherosclerosis progression study. Stroke 2007:1774-1779.

25. Blackburn R, Giral P, Bruckert E, Andre JM, Gonbert S, Bernard M, Chapman MJ, Turpin G: Elevated C-reactive protein constitutes an independent predictor of advanced carotid plaques in dyslipidemic subjects. Arterioscler Thromb Vasc Biol 200I:1962-1968.

26. Hansson GK, Libby $P$ : The immune response in atherosclerosis: a double-edged sword. Nat Rev Immunol 2006:508-5I9.

27. Clapp BR, Hirschfield GM, Storry C, Gallimore JR, Stidwill RP, Singer M, Deanfield JE, MacAllister RJ, Pepys MB, Vallance P, Hingorani AD: Inflammation and endothelial function: direct vascular effects of human C-reactive protein on nitric oxide bioavailability. Circulation 2005:1530-1536.

28. Sabatine MS, Morrow DA, Jablonski KA, Rice MM, Warnica JW, Domanski MJ, Hsia J, Gersh BJ, Rifai N, Ridker PM, Pfeffer MA, Braun- wald E: Prognostic significance of the Centers for Disease Control/Am Heart Association high-sensitivity C-reactive protein cut points for cardiovascular and other outcomes in patients with stable coronary artery disease. Circulation 2007:1528-1536.

29. Tsimikas S, Willerson JT, Ridker PM: C-reactive protein and other emerging blood biomarkers to optimize risk stratification of vulnerable patients. J Am Coll Cardiol 2006:CI9-C3I.

30. Hasday JD, Bascom R, Costa J], Fitzgerald T, Dubin W: Bacterial endotoxin is an active component of cigarette smoke. Chest 1999:829-835

31. Lowe GD, Pepys MB: C-reactive protein and cardiovascular disease: weighing the evidence. Curr Atheroscler Rep 2006:42I-428.

32. Pepys MB: CRP or not CRP? That is the question. Arterioscler Thromb Vasc Biol 2005: 1091-1094.

33. Chang MK, Binder CJ, Torzewski M, Witztum JL: C-reactive protein binds to both oxidized LDL and apoptotic cells through recognition of a common ligand: Phosphorylcholine of oxidized phospholipids. Proc Natl Acad Sci USA 2002: 13043-13048.

34. Verma S, Devaraj $S$, Jialal I: Is C-reactive protein an innocent bystander or proatherogenic culprit? C-reactive protein promotes atherothrombosis. Circulation 2006:2/35-2/50.
Publish with Bio Med Central and every scientist can read your work free of charge

"BioMed Central will be the most significant development for disseminating the results of biomedical research in our lifetime. "

Sir Paul Nurse, Cancer Research UK

Your research papers will be:

- available free of charge to the entire biomedical community

- peer reviewed and published immediately upon acceptance

- cited in PubMed and archived on PubMed Central

- yours - you keep the copyright

Submit your manuscript here:

http://www.biomedcentral.com/info/publishing_adv.asp
BioMedcentral 